\title{
The Benefit of Utilizing E-Government Based Public
}

\section{Services}

DOI: https://doi.org/10.47175/rissj.v1i3.114

\section{| Muhammad Iqbal' ${ }^{1}$ Julia Ivanna ${ }^{2}$ | Sri Hadiningrum ${ }^{3}$ |}

\author{
${ }^{1}$ Department of \\ Anthropology Education, \\ University of State Medan, \\ Indonesia. \\ 2,3 Department of Civic and \\ Pancasila Education, \\ University of State Medan, \\ Indonesia
}

iqbal81@unimed.ac.id

\begin{abstract}
The aim of this article to research government efforts in the implementation of bureaucracy reform as stipulated in the law No. 25 of 2009 about public services related to the service to its residents with quality service standards, fast, easy, affordable and be measured. It is in accordance with Presidential Instruction No. 3 of 2003 about national policy on e-Government development. In its development, e-Government is still far from expectations, government institutions both in the center and the region do not yet consider the important e-Government. E-Government is considered a project and a momentarily trend. Kecamatan Medan barat where the research will be done one of the sub-districts in Medan that has been conducting bureaucracy reform by providing public services based on electronic (e-kecamatan) in managing Administration and Increase Community participation. This study uses qualitative research methods with the type of descriptive research. The results showed the success of public services electronic-based public services in Kecamatan Medan Barat had a prerequisite, namely (1) the support from the District Leadership (Camat), (2) availability of Financial Resources and Human Resources (3) Transparency In the public service process with application system. In addition, e-kecamatan based services facilitate the residents to obtain information and manage various purposes in the form of administrative services products KEYWORDS

E-Government, Kecamatan Medan Barat, E-Kecamatan
\end{abstract}

\section{INTRODUCTION}

Along with the development of information and communication technology, the state in this case the government is required to be part of the global community. Technology has become a fundamental demand of public services carried out by the government in order to achieve effective and efficient public services. There has been a change in the utilization of Information, Communication and Technology (ICT) where human activities in various sectors have also changed, as well as in the public service sector by the government.

Government efforts in implementing bureaucratic reform as regulated in Law no. 25 of 2009 concerning Public Services which is providing services to its citizens with quality standards of service, fast, easy, affordable and measurable continues to be done. The government's efforts were supported by the issuance of Presidential Instruction Number 3 of 2003 concerning the National Policy for the Development of E-Government in the administration of electronic-based government or often referred to as Electronic Government (e-government).

The use of e-Government in order to realize the principles of open government has been regulated in Law No. 14 of 2008 concerning Openness of Public Information where every 
citizen has the right to obtain public information. The use of e-Government at the local government level is still based on the initiative and commitment of regional heads. These innovations are related to the use of information and communication technology in supporting services to the community.

In its development, e-Government is still far from expectations. Government institutions both at central and regional levels do not yet consider e-government importance. EGovernment is considered as a project and momentary trend in government circles. It is found that some local government websites are not well managed and maintained. That financial information uploaded on government sites is still difficult to understand, and the public still has limited access. The limited regulation as a legal umbrella and the limited competent experts in the field of informatics engineering are obstacles to the success of eGovernment. Not yet integrated data between government agencies is also an obstacle because each agency has one data program with a different format. Inadequate budgeting, lack of standardization of infrastructure and the lack of information security in implementing e-Government are also cited as the causes of e-Government's lack of success so far.

Kecamatan Medan Barat, one of the sub-districts in the city of Medan, which has now carried out bureaucratic reform by signing a service announcement to carry out public services in accordance with the Service Standards that have been set in accordance with applicable laws and regulations. Ironically, the website of Medan Barat District shows that the website is left neglected, lacks information and data, even the website has not been updated for a long time. So far, it has been very difficult to get data from the official government website.

So that With the openness of data and information it can be a reference for government, society and other stakeholders to contribute to find solutions to the problems at hand. Even for government suggestions or public complaints can be used as a reference in make a strategic policy. Thus it is necessary to follow the development of e-Government management in public services in Medan City, especially at the level. The sub-district, namely West Medan District, has succeeded in implementing e-Government.

\section{REVIEW OF LITERATURE}

\section{The concept of E-Government}

According to Heeks (2006): "The emphasis of e-Government is not on "e", buton "Government" to remind that in E-Government, tasks main government is to organize and regulate the whole society. E-Government must be viewed from an approach technology and the public sector".Wescott (in Mana et al., 2015) says that E-Government use information and communication technology (ICT) to promoting more efficient governance and lowering costs effective, ease of government service facilities and provide access information towards the general public, and make more governance responsible to society.

\section{Electronic Government Development Stages}

In the Presidential Instruction (Inpres) No. 3 of 2003 concerning the National Policy and Strategy for E-Government Development, it is explained that the implementation of EGovernment in each government institution refers to the stages of E-Government development nationally, and is adjusted to the existing conditions in each government institution which includes: 
1. Priority electronic services to be provided;

2. The condition of the information infrastructure owned;

3. Current condition of service activities;

4. The condition of the budget and human resources owned

\section{Key Factors to E-Government Success}

According to the results of studies and research from the Harvard JFK School of Government (Indrajit, 2004: 15), in order to apply the concepts of digitization to the public sector, there are three elements of success that must be had and really paid attention to. Each of these elements of success are:

\section{Support}

The first and most crucial element that the government must have is the desire (intent) of various circles of public and political officials to actually implement the concept of $\mathbf{E}$ Government, not just following trends or opposing initiatives related to the principles of E-Government. .

Without this "Political Will" element, various initiatives E-Government development and development will not go well. What is meant by support here is not just talk, but further support that is expected is in the form of the following:

1) The agreement on the E-Government framework is one of the keys to the country's success in achieving the vision and mission of its nation, so it must be given high priority.

2) The dissemination of the concept of E-Government evenly, continuously, consistent and comprehensive to all bureaucrats and the general public through various sympathetic campaigning means.

\section{Capacity}

There is the ability or empowerment of the local government in making the related EGovernment "dreams" come true. There are three things that must be owned by the government in connection with these elements, namely:

1) Availability of sufficient resources to carry out various E-Government initiatives, especially those related to financial resources.

2) Availability of adequate information technology infrastructure, this is $50 \%$ of the keys to the successful implementation of E-Government.

3) Availability of competent human resources the expertise needed to make EGovernment adoption appropriate with the principle of the expected benefits.

3. Value

The first and second elements are the two aspects seen from the government side as the service provider (supply side). Various E-Government initiatives will be of no use if neither party benefits from the implementation of the concept. In this case, what determines whether or not the benefits obtained by the existence of E-Government are not the government itself, but the community and those with an interest (demand side).

For this reason, the government must be really careful in choosing priority types of $\mathbf{E}$ Government applications that must take precedence development so that it actually provides significant benefits (value) felt by the community.

\section{RESEARCH METHODS}

This study uses qualitative research methods with the type of descriptive research. The use of descriptive types is intended as a problem-solving procedure that is investigated by 
describing or describing the condition of the subject or object under study (a person, institution, society, etc.) at the present time based on the facts that appear or as they are [8]. The focus of this research is the implementation of the E-Government program in the Medan Barat District in the City of Medan. This research tries to describe the phenomena / events that exist in the application of E-Government in Medan Barat Sub-District in the City of Medan as a form of service to the public using information technology in its implementation.

\section{RESULT AND DISCUSSION}

Medan government manages all administrations try to implement E-Government well that has been running for 3 years. The vision and mission are stated in the form of Mayor Regulation (Perwal), namely the existence of Perwal No. 28 of 2018, then proceed with the issuance of Mayor Decree related to ICT services where this regulation is in the form of smart city council for the period of 2017-2020. Not all OPDs belong to the smart city team. The smart city team only consists of the OPD who need a special system.

To save a budget Medan City that estimated about over thousands of millions to create a program for an application. Medan city decide to corporate with other cities or districts that have already developed the E- Government or Smart City ecosystem. So, Medan city signed a MoU with Tangerang City in September 2018. The reason is that the sharing application can save a budget. Medan City can adopt and modify it without the need to design. But it still needed the modification of the application and it must be adapted to the needs of the City of Medan. Because Medan's E-Government needs must not be the same as the needs of other cities. So that if it is going to adopt an E-Government application it can't necessarily be used directly from the place of origin but it certainly has to be adjusted so that it doesn't cause friction due to non-compliance needs. This is influenced by culture, geographical location and others. After that Medan City implemented well. And then it succeeded in getting a ranking of 43 out of 140 Smart City cities in Indonesia.

For each of the OPD levels determine their own needs for menus, features and content on the website. it's only a basic web from Diskominfo. Uniformity of basic public service menus such as requests for E-KTP, heirs in each sub-district is very important. However, not all districts run E-Government (e-kecamatan) based public services. In the case of the eGovernment development budget sourced from the APBD, a budget proposal is submitted annually. Diskominfo only spends the budget when making applications and installing wifi, while after the web and wifi is available it will be submitted to each OPD. For budget submissions, it is recommended $100 \%$, the percentage of proposals that are realized is $90 \%$.

The availability of financial resources is very much needed for the successful development of E-Kecamatan. In terms of budget, each sub-district proposes a different nominal as needed in applying the E-Subdistrict application to the Medan City Government. Human resources are the main and most important asset in carrying out the management and operations of the organization. Qualification of human resources both educational background and experience in their fields will determine the success of the organization's tasks and functions. When viewed from qualifications or educational background, the Medan Office of Communication and Information does not yet have a good staffing structure. The weakness is particularly evident in the educational background where only 8 civil servants or 0.19 percent have an educational background that matches the field of work handled by the Diskominfo.

Furthermore, for the availability of human resources in the kecamatan Medan Barat, where the availability of experts for E-Subdistrict services consists of two people with a Bachelor's education background in economics.Availability of adequate information technology infrastructure is $50 \%$ of the keys to the successful implementation of $\mathrm{E}$ - 
Government[10] In terms of infrastructure, the Medan City Government provides internet network (wifi) and continues to work closely with telecommunications service providers. Telkom, Indosat and other providers such as PLN, TNC, INET, MEDIA NUSA, city hall from PRESS MEDIA (CHANNEL TV) so that E-Government can be accessed by the public. For the smooth implementation of E-Kecamatan in Medan Barat, there are already computers and other supporting infrastructure available to support the implementation of Ekecamatan. The official appearance of the Kecamatan Medan Barat website can be seen in www.medanbarat.pemkomedan.go.id

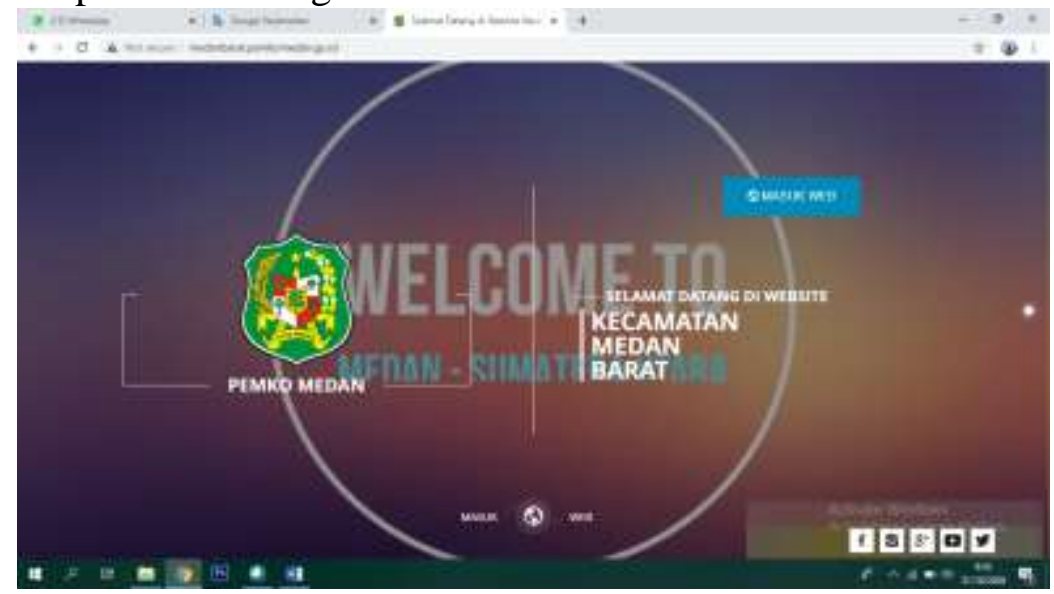

Figure. 1. Medan Barat Website

E-Kecamatan is an online application service districts and a subdistrict-level administrative management website designed and developed by the Medan city government to provide convenience to the people of Medan Barat District. But in website is not only for providing administrative services but also some kinds of information displayed about Kecamatan Medan Barat such as: Religion, Health, Community, Sports, Market, Government, Education, Art, Uncategorized, and Tourism.

So from these some categories can provide various information and news about the activities, work programs and policies of the West Medan District Government. And all societies in Kecamatan Medan Barat keep in touch with Medan City government. As the data show that the use of social media the West Medan District Government is very active both on Twitter, Facebook and Instagram and almost all the people have social media. So this is a good strategy of the West Medan District Government to provide information and greet their citizens easily. For social medias like facebook, twitter, instagram of Kecamatan Medan Barat are linked to the website. The aim is to report routine sub-district activities, such as mutual cooperation which is held every Tuesday and Thursday. Documentation of activities uploaded to social media in order to be able to notify and invite the public to participate.

The platform uses Indonesian, where direct communication cannot be done on the website between the West Medan District Government and the community. But the E-Kecamatan application system that would be built and be developed further. Until it can be used to communicate directly. But it must be first discussed with Diskominfo so that it could be made as easy and as simple as possible so that residents could use it. 


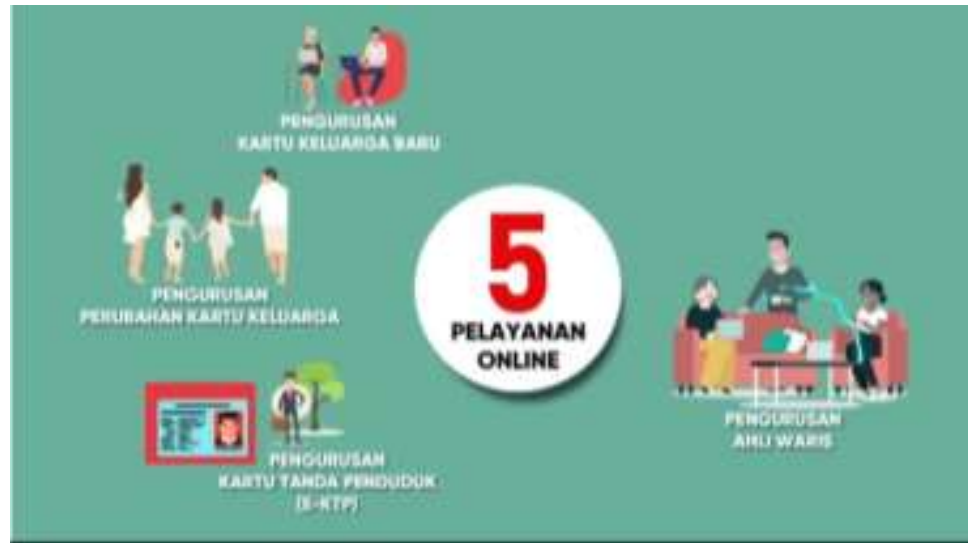

Figure. 2. The display of web of E-Kecamatan Medan Barat

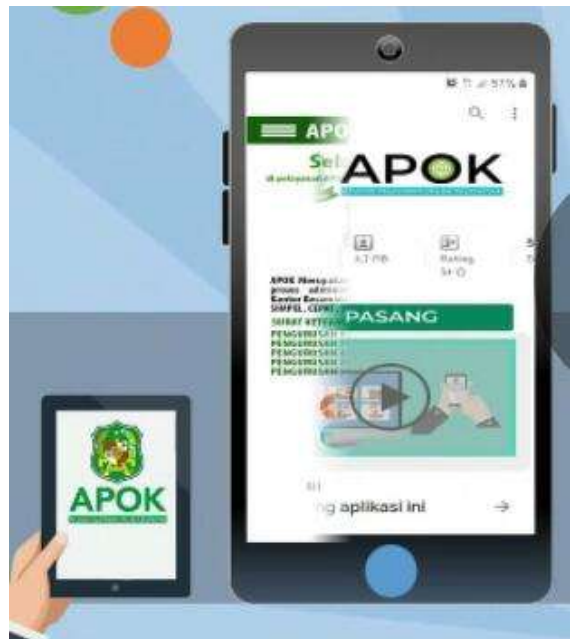

Figure. 3. The Display of Web of Android version

The West Medan District Public Service Application can also be downloaded on Android freely. So that every resident of West Medan District can download the E-Kecamatan application anywhere and anytime. In this application there are 5 types of services available including Request for New Indonesian Citizen Card, Request for Indonesian Citizen Card, Request for Indonesian Citizen Card (E-KTP) for New Indonesian Citizen, Request for Statement of Heirs, Request for Certificate of Moving Arrival. However, for further solutions such as correspondence, the sub-district cannot process and complete the product directly, for example in the handling of the Family Card (KK) in the sub-district it cannot be completed immediately, but there is still a further process where files will be submitted to the office, the task of the village is only processing in attaching data or as an intermediary, after which it is sent to Disdukcapil.

Likewise, in the letter of the moving committee, first a letter from the head of the ward is then scanned together with the KTP and family card. Then uploaded to the E-district application. Kecamatan Medan Barat built an android application system to support district administration service products. Through E-Kecamatan application, the people of Kecamatan Medan Barat who want to get administrative services can directly use an Android or open the E-Kecamatan website at the link http://medanbarat.pemkomedan.go.id/.

The government must be able choose carefully what types of applications should take precedence in order to truly provide benefits (value) that are significantly felt by the community. There are two elements that must be looked by the government in providing 
public services (supply side) including Support and capacity elements. Both of these elements can be useful if they can provide benefits for the interests of the community (demand side).

Based on the results of interviews with several people who used Kecamatan Medan Barat website and application, the community felt it was helped because in administrative matters there was no need to go and back to the district office. It only need to complete the file and send the requirements into the application according to the required administrative application. It's just that in the process of completing several types of services it takes a long time. This is because the final product in the administrative process required by the community has not been completed in the sub-district. The product is completed at the related office because in the management of e-KTP the final product is filled in at the Population and Civil Registry Office (Capil).

The benefits of E-Kecamatan applications are also only felt by some people who understand how to use technology. The society consists of millennial and workers who are already familiar with using technology. Whereas for the elderly lay people it's easier to take care of administration by hand or by coming directly to the district office. It only accesses the web of http://medanbarat.pemkomedan.go.id and then consist all the administrations appropriate with use to. All can be finish fast and easily.

\section{CONCLUSION}

From the results of the study it can be concluded that the implementation of e- Government based public services has optimally. This can be seen from the high commitment of leaders. Public services through E-kecamatan is the answer or response from the government of Kecamatan Medan barat on the demand to improve the quality of public services, especially in administrative services will be more effective and efficient. The benefit of utilizing Ekecamatan application is very useful. The citizens can access various information and look for the needs related to administrative service products, such as family card applications (Kartu keluarga), E-KTP, application for moving certificates) easily and quickly. The government also is very helped with this application.

\section{REFERENCES}

P. I. Indonesia. (2015), Undang-Undang Republik Indonesia No. 25 Tahun 2009 Tentang Pelayanan Publik.

P. R. Indonesia. (2006), “Instruksi Presiden Republik Indonesia Nomor 3 Tahun 2003 tentang Kebijakan dan Strategi Nasional Pengembangan E-Government." Deputi Sekretaris Kabinet Bidang Hukum dan Perundang-undangan.

R. I. Indonesia. (2015), “Undang-Undang Republik Indonesia No. 14 Tahun 2008 Tentang Keterbukaan Informasi Publik,"

B. Rahardjo. (2001), "Membangun E-Government," in Makalah dipresentasikan pada Seminar Nasional Jaringan Komputer II diselenggarakan oleh Technic Study Club, STMIK Dipanegara Makassar, vol. 19.

E. A. Sosiawan. (2015), "Evaluasi implementasi E-Government pada situs web pemerintah daerah di Indonesia: Prespektif content dan manajemen," in Seminar Nasional Informatika (SEMNASIF), vol. 1, no. 5.

Y. C. Chen and J. Gant. (2001), "Transforming local E-Government services: The use of application service providers," Gov. Inf. Q., vol. 18, no. 4, pp. 343-355 
N. Hidayati (2016), "E-Government Dalam Pelayanan Publik (Studi Kasus tentang Faktorfaktor Penghambat Inovasi Layanan E-Samsat Jatim di Kabupaten Gresik)," Mhs. Progr. Stud. Ilmu Adm. Negara, FISIP, Univ. Airlangga, Kebijak. dan Manaj. Publik, vol. 4.

J. W. Creswell and J. D. Creswell. (2017), Research design: Qualitative, quantitative, and mixed methods approaches. Sage publications

A. Ricky. (2018), "SK SMART CITY 2018,".

I. R. Eko. (2005), "E-Government in action," Andi, Yogyakarta

R. Heeks. (2001), Reinventing government in the information age: International practice in IT-enabled public sector reform, vol. 1. Psychology Press 